\title{
Increased apoptosis in bovine blastocysts exposed to high levels of IGF1 is not associated with downregulation of the IGF1 receptor
}

\author{
M A Velazquez ${ }^{1,2}$, D Hermann ${ }^{1}$, W A Kues $^{1}$ and H Niemann ${ }^{1}$ \\ ${ }^{1}$ Department of Biotechnology, Institute of Farm Animal Genetics, Friedrich-Loeffler-Institut (FLI), Höltystrasse 10, \\ Mariensee, 31535 Neustadt, Germany and ${ }^{2}$ Escuela Superior de Ciencias Agropecuarias, Universidad Autónoma de \\ Campeche, Calle 53 s/n, CP 24350 Escárcega, Campeche, Mexico
}

Correspondence should be addressed to H Niemann; Email: heiner.niemann@fli.bund.de

\begin{abstract}
The hypothesis that high concentrations of IGF1 can impair embryo development was investigated in a bovine in vitro model to reflect conditions in polycystic ovary syndrome (PCOS) patients. Embryos were either cultured in the absence or presence of a physiological $(100 \mathrm{ng} / \mathrm{ml})$ or supraphysiological $(1000 \mathrm{ng} / \mathrm{ml})$ IGF1 concentration. Cell allocation, apoptosis, transcript and protein expression of selected genes involved in apoptosis, glucose metabolism and the IGF system were analysed. Supraphysiological IGF1 concentration did not improve blastocyst formation over controls, but induced higher levels of apoptosis, decreased TP53 protein expression in the trophectoderm and increased the number of cells in the inner cell mass (ICM). The increase in ICM cells corresponded with an increase in IGF1 receptor (IGF1R) protein in the ICM. A small, but significant, percentage of blastocysts displayed a hypertrophic ICM, not observed in controls and virtually absent in embryos treated with physiological concentrations of IGF1. Physiological IGF1 concentrations increased total IGF1R protein expression and upregulated IGFBP3 transcripts leading to an increase in blastocyst formation with no effects on cell number or apoptosis. In conclusion, the results support the hypothesis of detrimental effects of supraphysiological IGF1 concentrations on early pregnancy. However, our results do not support the premise that increased apoptosis associated with high levels of IGF1 is mediated via downregulation of the IGF1R as previously found in preimplantation mouse embryos. This in vitro system with the bovine preimplantation embryo reflects critical features of fertility in PCOS patients and could thus serve as a useful model for in-depth mechanistic studies.
\end{abstract}

Reproduction (2011) $14191-103$

\section{Introduction}

The insulin-like growth factor (IGF) system is a critical signalling mechanism disrupted by hyperinsulinaemia in conditions such as the polycystic ovary syndrome (PCOS; Essah et al. 2004). Hyperinsulinaemia has been suggested to be a risk factor for miscarriage in PCOS patients (van der Spuy \& Dyer 2004, Cocksedge et al. 2008) and has been proposed as a main factor in the pathophysiology of early pregnancy loss in PCOS patients (Essah et al. 2004). The increased insulin levels reduce synthesis of IGF binding proteins (IGFBPs) such as IGFBP1, which in turn enhances bioactivity of IGF1 (Wang \& Chard 1999). High concentrations of free IGF1 affect endometrial function with deteriorating effects on implantation (Lathi et al. 2002, Giudice 2006). Exposure of rodent embryos to increased concentrations of IGF1 in vivo or in vitro resulted in abnormal preimplantation embryo development (Katagiri et al. 1996, 1997). These findings led to the hypothesis that high IGF1 concentrations are partially responsible for the early pregnancy losses observed in PCOS patients (Chi et al. 2000). To test this hypothesis, murine embryos were cultured in vitro in the presence of IGF1 concentrations ranging from 950 to $1500 \mathrm{ng} / \mathrm{ml}$. These high levels of IGF1 induced apoptosis in blastocysts via downregulation of the IGF1 receptor (IGF1R; Chi et al. 2000, Eng et al. 2007), which resulted in increased resorption rates after transfer to recipients (Pinto et al. 2002, Eng et al. 2007).

Current data indicate that high IGF1 concentrations downregulate the IGF1R in mouse embryos causing a decrease in glucose uptake associated with reduced activation of the AMP kinase (Chi et al. 2000, Pinto et al. 2002, Eng et al. 2007, Louden et al. 2008). IGF1-induced apoptosis in murine blastocysts is dependent on expression of BAX, TP53 and caspases (1, 3 and 8) (Chi et al. 2000, Moley et al. 2005). In contrast, downregulation of IGF1R has been reported in bovine embryos exposed to IGF1 at physiological 
concentrations (100 ng/ml; Prelle et al. 2001, Block et al. 2008). In fact, transfer of in vitro-produced bovine embryos treated with $100 \mathrm{ng} / \mathrm{ml}$ IGF1 improved both pregnancy and calving rates in lactating cows suffering from heat stress (Block et al. 2003, Block \& Hansen 2007). An IGF1 dose-dependent decrease in IGF1R expression was reported in mouse embryos (Chi et al. 2000) and whether this occurs in bovine embryos is unknown at present. With the exception of one report (Inzunza et al. 2010), the general consensus is that mouse embryos start expressing IGF1R at the eight-cell stage (Smith et al. 1993, Stojanov \& O'Neill 2001, Markham \& Kaye 2003), whereas in human, porcine and bovine embryos IGF1R is expressed throughout the preimplantation period (Watson et al. 1992, Lighten et al. 1997, Yaseen et al. 2001, Kim et al. 2005). This highlights the importance of using alternative animal models to laboratory mice for investigations on humanrelated endocrine pathologies. Since Bos taurus is a good model species for early human embryo development (Ménézo \& Hérubel 2002, Baumann et al. 2007, Kues et al. 2008, Velazquez 2008), bovine in vitro embryo production (IVP) could provide a good experimental model system for unravelling mechanisms involved in the putative impaired development of embryos exposed to high concentrations of IGF1. A cross-species microarray hybridisation study revealed that gene expression profiles in bovine and human blastocysts were to a large extent identical (Adjaye et al. 2007). Similarly, the transcription profiles during maternal-zygotic transition are similar between the two species (Xie et al. 2010). Furthermore, the amino acid sequence of bovine IGF1 is identical to that of human IGF1 (Honegger \& Humbel 1986, Francis et al. 1988). In both the species, supplementation with physiological concentrations of human recombinant IGF1 can exert positive effects on in vitro preimplantation embryo development (Lighten et al. 1998, Spanos et al. 2000, Byrne et al. 2002, Makarevich \& Markkula 2002).

IGF1 has anti-apoptotic activities, and exerts strong mitogenic effects on several mammalian cell types (Benito et al. 1996) including blastomeres from preimplantation embryos. For instance, early embryos exposed to physiological concentrations of IGF1 $(50-150 \mathrm{ng} / \mathrm{ml})$ showed an increased number of cells in the resulting blastocysts in several mammalian species including mice (Lin et al. 2003, Głabowski et al. 2005), gerbil (Yoshida et al. 2009), cattle (Byrne et al. 2002, Makarevich \& Markkula 2002, Sirisathien et al. 2003, Jousan \& Hansen 2007), buffaloes (Narula et al. 1996), pigs (Kim et al. 2005, 2006), rabbits (Herrler et al. 1998) and humans (Lighten et al. 1998). Physiological (100 ng/ $\mathrm{ml}$ ) and supraphysiological $(1000 \mathrm{ng} / \mathrm{ml})$ concentrations of IGF1 increased the total cell number (TCN) in mice embryos in a dose-dependent manner (Głabowski et al. 2005). It is unknown whether the IGF1-induced increase in the number of cells in murine embryos is associated with an elevated apoptotic index (Chi et al. 2000). The effects of high concentrations of IGF1 on cell allocation in preimplantation embryos, which is a critical factor for a successful pregnancy, have not yet been investigated. Unravelling the mechanisms by which high concentrations of IGF1 interfere with normal embryonic development could be beneficial for the development of more efficient therapies in PCOS patients.

The goal of this study was to determine the effects of supraphysiological concentrations of IGF1 on preimplantation bovine embryos. We evaluated cellular and molecular characteristics of in vitro-produced bovine blastocysts exposed to physiological or supraphysiological concentrations of IGF1 from the zygote stage onwards. The parameters analysed at the blastocyst stage included cell allocation, frequency of apoptosis, protein expression of the IGF1R and TP53 gene and transcript abundance of selected genes involved in apoptosis, glucose metabolism and the IGF system.

\section{Results \\ Preimplantation embryo development}

Cleavage rates were not affected by IGF1 supplementation. However, the total rate of blastocyst formation was increased significantly by $100 \mathrm{ng} / \mathrm{ml}$ IGF1 compared with controls $(P=0.005)$ and $1000 \mathrm{ng} / \mathrm{ml}$ IGF1 ( $P=0.035$; Table 1$)$. The $100 \mathrm{ng} / \mathrm{ml}$ IGF1 group had fewer degenerated embryos than the control $(P=0.014)$ and the supraphysiological IGF1 group $(P=0.018)$. The rate of blastocyst formation and degenerated embryos did not differ significantly between the control and the $1000 \mathrm{ng} / \mathrm{ml}$ IGF1 group (Table 1). The proportion of replicates in which blastocyst formation was increased over controls was higher for $100 \mathrm{ng} / \mathrm{ml}$ IGF1 than for $1000 \mathrm{ng} / \mathrm{ml} \mathrm{IGF1} \mathrm{(80.6} \mathrm{vs} 51.6 \%, P=0.32$ ).

\section{Differential cell staining and detection of apoptosis by TUNEL}

The number of cells in the inner cell mass (ICM) was similar in the control and the $100 \mathrm{ng} / \mathrm{ml} \mathrm{IGF1} \mathrm{group.} \mathrm{The}$ supraphysiological IGF1 concentration increased the number of ICM cells over controls $(P=0.005)$ and the $100 \mathrm{ng} / \mathrm{ml} \mathrm{IGF1} \mathrm{group}(P=0.003)$. The number of cells in the trophectoderm (TE) did not differ between the three groups (Table 2). Mean values for ratio of TE to ICM cells and the proportion of ICM to the TCN (ICM/TCN) were not affected by IGF1 treatment (Table 2). However, a significant percentage of blastocysts in the $1000 \mathrm{ng} / \mathrm{ml}$ IGF1 group displayed an increased ICM/TCN proportion $(>40)$ compared with the control $(P=0.006)$ and the $100 \mathrm{ng} / \mathrm{ml}$ IGF1 group $(P=0.006$; Fig. 1$)$. The control $(P=0.001)$ and the $100 \mathrm{ng} / \mathrm{ml}$ IGF1 group $(P=0.006)$ had a higher percentage of blastocysts with a $20-40 \mathrm{ICM} / \mathrm{TCN}$ proportion than the supraphysiological IGF1 group. 
Table 1 Effects of different insulin-like growth factor 1 (IGF1) concentrations on the in vitro development of bovine embryos.

\begin{tabular}{|c|c|c|c|}
\hline Parameters & Control $(n=1200)^{\mathrm{a}}$ & $100 \mathbf{~ n g} / \mathbf{m l}$ IGF1 $(n=1200)^{\mathrm{a}}$ & $1000 \mathbf{~ n g} / \mathbf{m l}$ IGF1 $(n=1200)^{\mathrm{a}}$ \\
\hline & Mea & $(n)^{b}$ & \\
\hline Cleavage $^{\mathrm{c}}(\%)$ & & & 5 \\
\hline$(\%)$ & 96) & 15) & (87) \\
\hline )) & 5) (194) & ) (219) & ) (208) \\
\hline & & & 27) \\
\hline (\%) & $5-2.3(0.0-4.4)(29)$ & $-2.8(0.0-6.7)(54)$ & $3.8+0.6-2.8(0.5-5.7)(47)$ \\
\hline Total blastocysts (\%) & $28.9 \pm 1.5 *-28.5(23.5-34.2)(350)$ & $34.9 \pm 1.4^{+}-32.6(30.6-40.0)(420)$ & $30.4 \pm 1.5^{*}-31.4(24.6-37.0)(369)$ \\
\hline Degenerated embryos $^{\mathrm{d}}(\%)$ & $47.5 \pm 2.3^{*}-47.6(39.4-58.2)(329)$ & $38.5 \pm 2.7^{+}-42.1(27.3-51.1)(287)$ & $47.2 \pm 2.7^{*}-46.6(35.4-61.1)(338)$ \\
\hline
\end{tabular}

${ }_{*,+}$ Values within rows with different superscripts differ significantly $(P \leq 0.05)$.

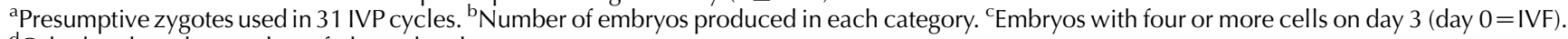

${ }^{\mathrm{d}}$ Calculated on the number of cleaved embryos.

The percentage of blastocysts showing an ICM/TCN proportion $<20$ was not statistically different between the three groups (Fig. 1).

The percentage of embryos with at least one apoptotic blastomere were higher in the $1000 \mathrm{ng} / \mathrm{ml}$ IGF1 (98.6\%) group compared with the control (88\%) group $(P=0.026)$. There were no differences in this regard between the control and physiological IGF1 group $(93.5 \%)$ or between the two IGF1 groups. No significant differences were found in any of the apoptotic parameters analysed between the controls and the $100 \mathrm{ng} / \mathrm{ml} \mathrm{IGF1}$ group. In contrast, embryos treated with $1000 \mathrm{ng} / \mathrm{ml} \mathrm{IGF1}$ showed more apoptotic cells in ICM $(P<0.001)$ and TE $(P=0.004)$ than embryos in the control and the $100 \mathrm{ng} / \mathrm{ml}$ IGF1 group (Table 2). This was reflected in a higher number of total apoptotic cells $(P<0.001)$ and in an increased apoptotic index $(P<0.001)$ in the supraphysiological group compared with the control and $100 \mathrm{ng} /$ ml IGF1 groups (Table 2). The number of apoptotic cells was not dependent on the number of cells in any of the groups as indicated by low coefficients of correlation (control: $r^{2}=0.0858 ; 100 \mathrm{ng} / \mathrm{ml}$ IGF1: $r^{2}=0.0993$; $1000 \mathrm{ng} / \mathrm{ml}$ IGF1: $\left.r^{2}=0.0047\right)$. TCN was increased in $1000 \mathrm{ng} / \mathrm{ml}$ IGF1 compared with the control $(P=0.005)$ and $100 \mathrm{ng} / \mathrm{ml} \mathrm{IGF1} \mathrm{groups}(P=0.01)$ respectively. There were no differences in this regard between the control and the $100 \mathrm{ng} / \mathrm{ml} \mathrm{IGF1}$ group (Table 2).

\section{mRNA transcript expression}

Supplementation with IGF1 did not affect the relative abundance of transcripts for IGF1R, TP53 and SLC2A3. However, $100 \mathrm{ng} / \mathrm{ml}$ of IGF1 significantly increased transcript abundance of IGFBP3 ( $P=0.006$; Fig. 2$)$ and tended to increase the relative abundance of transcripts for SLC2A1 $(P=0.067)$ and SLC2A8 $(P=0.06)$ over that in embryos cultured in supraphysiological concentrations of IGF1. Transcript abundance for IGFBP3, SLC2A1 and SLC2A8 did not differ among the rest of the group combinations (i.e. control versus $100 \mathrm{ng} / \mathrm{ml}$

Table 2 Effects of different insulin-like growth factor 1 (IGF1) concentrations on cell number, cell allocation and apoptosis in bovine blastocysts produced in vitro.

\begin{tabular}{|c|c|c|c|}
\hline Parameters & Control & 100 ng/ml IGF1 & 1000 ng/ml IGF1 \\
\hline & $\begin{array}{l}\text { Mean } \pm \text { S.E.M. - median (Q1-Q3) } \\
(n)^{\mathrm{a}}\end{array}$ & $\begin{array}{l}\text { Mean } \pm \text { S.E.M. - median (Q1-Q3) } \\
(n)^{\mathrm{a}}\end{array}$ & $\begin{array}{l}\text { Mean } \pm \text { S.E.M. - median (Q1-Q3) } \\
(n)^{\mathrm{a}}\end{array}$ \\
\hline Cell number in the ICM & $\begin{array}{l}32.3 \pm 1.2^{*}-30.0(26.0-40.0) \\
\quad(\mathrm{DCS}=57)\end{array}$ & $\begin{array}{l}32.5 \pm 1.1^{*}-30.0(25.0-38.0) \\
\quad(\mathrm{DCS}=75)\end{array}$ & $\begin{array}{l}39.0 \pm 1.6^{+}-36.5(29.0-48.0) \\
\quad(\mathrm{DCS}=66)\end{array}$ \\
\hline Cell number in the TE & $\begin{array}{l}89.6 \pm 4.0-84.0(69.5-113.2) \\
\quad(\mathrm{DCS}=57)\end{array}$ & $\begin{array}{l}96.7 \pm 3.5-95.0(75.0-118.5) \\
\quad(\mathrm{DCS}=75)\end{array}$ & $\begin{array}{l}102.3 \pm 4.8-100.5(64.0-133.0) \\
\quad(\mathrm{DCS}=66)\end{array}$ \\
\hline Ratio TE:ICM & $\begin{array}{l}2.8 \pm 0.1-2.6(2.2-3.1) \\
\quad(\mathrm{DCS}=57)\end{array}$ & $\begin{array}{l}3.1 \pm 0.1-2.9(2.3-3.6) \\
\quad(\mathrm{DCS}=75)\end{array}$ & $\begin{array}{l}2.8 \pm 0.1-2.5(1.7-3.8) \\
\quad(\mathrm{DCS}=66)\end{array}$ \\
\hline Proportion ICM/TCN (\%) & $\begin{array}{l}27.2 \pm 0.7-27.6(24.2-30.6) \\
\quad(\mathrm{DCS}=57)\end{array}$ & $\begin{array}{l}25.8 \pm 0.7-25.5(21.3-29.8) \\
\quad(\mathrm{DCS}=75)\end{array}$ & $\begin{array}{l}28.8 \pm 1.1-28.5(20.6-36.0) \\
\quad(\mathrm{DCS}=66)\end{array}$ \\
\hline Apoptotic cells in ICM & $\begin{array}{l}1.3 \pm 0.2^{*}-0.0(0.0-2.0) \\
\quad(T U N E L=76)\end{array}$ & $\begin{array}{l}0.7 \pm 0.1^{*}-0.0(0.0-1.0) \\
\quad(T U N E L=77)\end{array}$ & $\begin{array}{l}2.2 \pm 0.3^{\dagger}-1.0(0.0-4.0) \\
\quad(\text { TUNEL }=73)\end{array}$ \\
\hline Apoptotic cells in TE & $\begin{array}{l}3.2 \pm 0.3^{*}-3.0(1.0-5.0) \\
\quad(T U N E L=76)\end{array}$ & $\begin{array}{l}3.8 \pm 0.3^{*}-3.0(1.0-5.0) \\
\quad(T U N E L=77)\end{array}$ & $\begin{array}{l}5.4 \pm 0.5^{+}-4.0(1.0-9.2) \\
\quad(\text { TUNEL }=73)\end{array}$ \\
\hline Total apoptotic cells & $\begin{array}{l}4.6 \pm 0.4^{*}-3.5(1.0-7.0) \\
\quad(\text { TUNEL }=76)\end{array}$ & $\begin{array}{l}4.5 \pm 0.4^{*}-4.0(2.0-6.2) \\
\quad(T U N E L=77)\end{array}$ & $\begin{array}{l}7.7 \pm 0.6^{\dagger}-7.0(3.7-12.0) \\
\quad(\text { TUNEL }=73)\end{array}$ \\
\hline Total apoptotic index (\%) & $\begin{array}{l}3.0 \pm 0.3^{*}-2.5(0.9-4.5) \\
\quad(\text { TUNEL }=76)\end{array}$ & $\begin{array}{l}2.9 \pm 0.2^{*}-2.1(1.4-3.6) \\
\quad(\text { TUNEL }=77)\end{array}$ & $\begin{array}{l}4.8 \pm 0.3^{\dagger}-5.0(2.3-6.7) \\
\quad(\text { TUNEL }=73)\end{array}$ \\
\hline Total number of cells & $\begin{array}{l}146.0 \pm 3.4^{*}-140.0(109.2-180.7) \\
\quad(\text { DCS-TUNEL-IF = 179) }\end{array}$ & $\begin{array}{l}147.1 \pm 3.3^{*}-135.0(111.0-170.2) \\
\quad(\mathrm{DCS}-\mathrm{TUNEL}-\mathrm{IF}=197)\end{array}$ & $\begin{array}{l}161.4 \pm 3.9^{\dagger}-151.0(119.5-199.2) \\
(\text { DCS-TUNEL-IF = 189) }\end{array}$ \\
\hline
\end{tabular}

$\mathrm{ICM}$, inner cell mass; TE, trophectoderm; TCN, total cell number. ${ }^{*}{ }^{\dagger}$ Values within rows with different superscripts differ significantly $(P \leq 0.05)$. ${ }^{a}$ Number of embryos used for differential cell staining (DCS), terminal deoxynucleotidyl transferase mediated dUTP nick end labelling (TUNEL) or immunofluorescence (IF). 


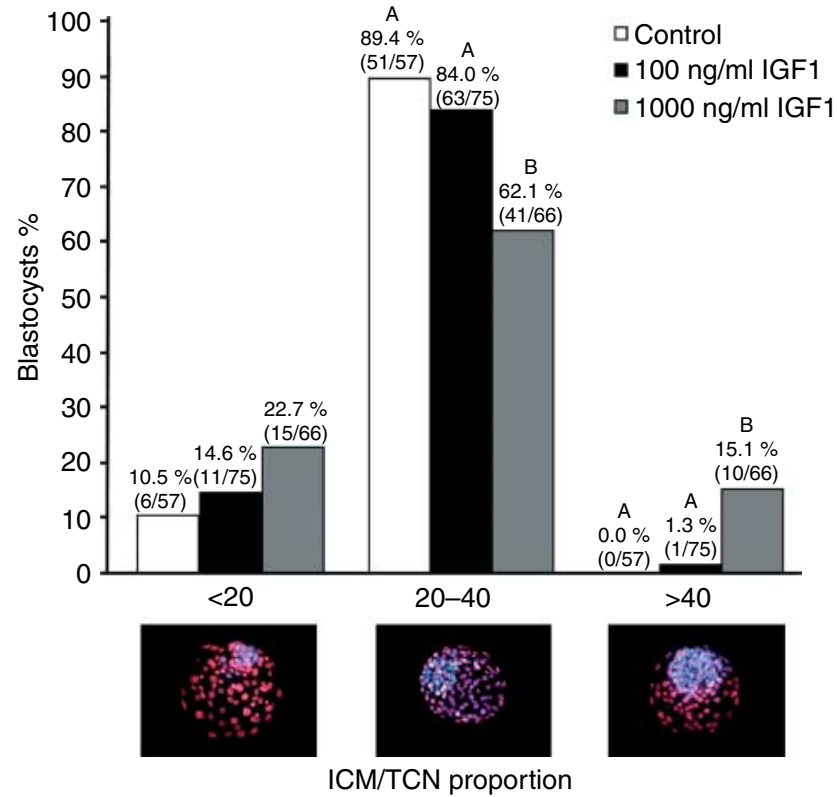

Figure 1 Effect of different IGF1 concentrations on the percentage of in vitro-produced blastocysts displaying different inner cell mass $(\mathrm{ICM})$ /total cell number (TCN) proportions. Within ICM/TCN categories, bars with different letters differ significantly $(P \leq 0.05)$.

IGF1; control versus 1000 ng/ml IGF1). Physiological concentrations of IGF1 tended to increase the relative expression of AKT1 transcripts compared with controls $(P=0.059)$, but not to $1000 \mathrm{ng} / \mathrm{ml}$ IGF1. Relative abundance of AKT1 did not differ between the control and the supraphysiological IGF1 group.

\section{IGF1R immunofluorescence}

The IGF1R was localised in both the ICM (ICM-positive) and TE in most of the blastocysts, predominantly in the cytoplasm (Fig. 3). However, a substantial proportion of blastocysts did not display IGF1R in the ICM (ICMnegative). The proportion of ICM-negative embryos did not differ significantly between the groups (control $=34.7 \%, 100 \mathrm{ng} / \mathrm{ml}$ IGF1 $=29.1 \%$ and $1000 \mathrm{ng} / \mathrm{ml}$ IGF1 $=50 \%$ ). In ICM-positive embryos, IGF1R was less expressed in the ICM than in the TE (Fig. 4). Less ICM immunofluorescence in ICM-positive embryos and ICMnegative staining was also observed in hatched blastocysts, indicating that the presence of the zona pellucida did not affect the results. No differences in relative signal strength (RSS) were found between the groups when all embryos were analysed together (i.e. ICM-positive and ICM-negative blastocysts). A second statistical analysis carried out in ICM-positive embryos revealed increased RSS in the ICM of embryos treated with $1000 \mathrm{ng} / \mathrm{ml} \mathrm{IGF1}(P=0.023)$ compared with the control group (Fig. 4). No significant differences in TE immunofluorescence were observed between high IGF1 treated and control embryos. Embryos treated with $100 \mathrm{ng} / \mathrm{ml}$ IGF1 tended to have more IGF1R immunofluorescence in the ICM $(P=0.076)$ and showed a significant increase in TE immunofluorescence ( $P=0.014)$ over controls (Fig. 4). Total RSS values for IGF1R were higher for $100 \mathrm{ng} / \mathrm{ml}$ IGF1 $(P=0.008)$ when compared with controls (Fig. 4). There were no significant differences in RSS values in IGF1 groups from ICM-positive embryos and between all groups in ICM-negative blastocysts. There was no correlation between the RSS values and the total number of nuclei in any of the groups.

\section{TP53 immunofluorescence}

The TP53 protein was observed in both the ICM and TE in most of the embryos (Fig. 3). Only a few blastocysts did not display TP53 in the ICM (control=2, $100 \mathrm{ng} / \mathrm{ml} \mathrm{IGF1=2}$ and $1000 \mathrm{ng} / \mathrm{ml} \mathrm{IGF1=1).} \mathrm{All} \mathrm{embryos} \mathrm{showed} \mathrm{cyto-}$ plasmic localisation of TP53 protein. RSS values were
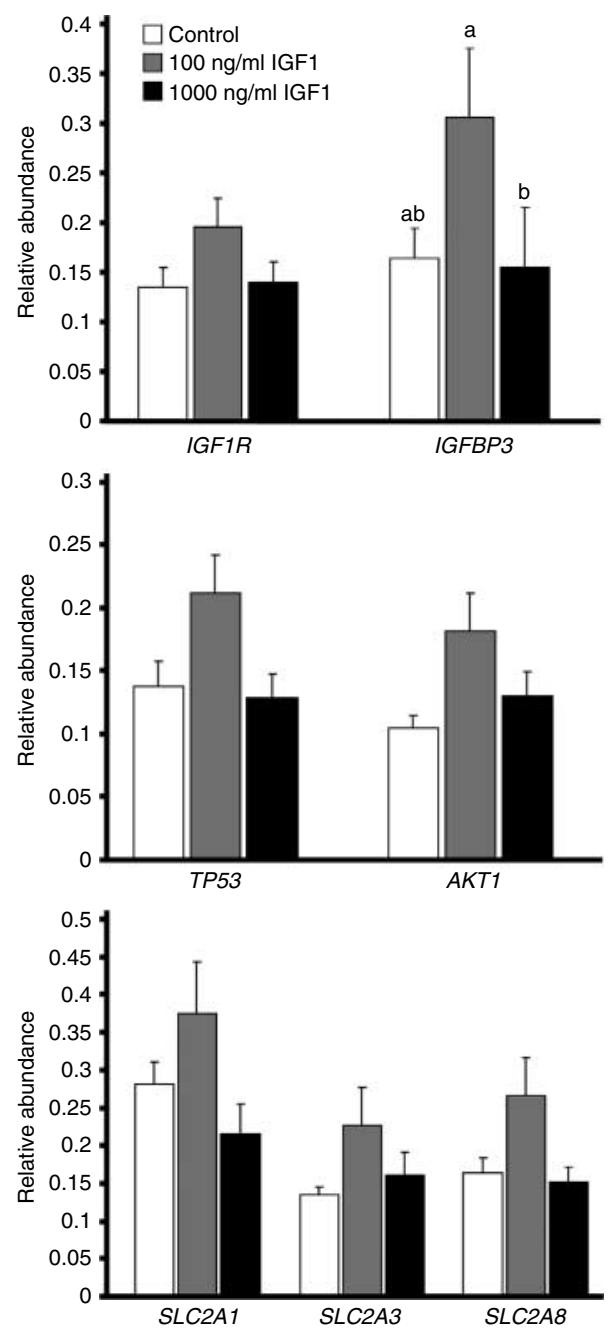

Figure 2 Relative transcript abundance (mean \pm S.E.M.) of developmentally important genes in day- 8 blastocysts cultured in the presence of different IGF1 concentrations from the zygote stage onwards. Bars with different superscripts within each gene transcript indicate a significant difference $(P \leq 0.05)$. 


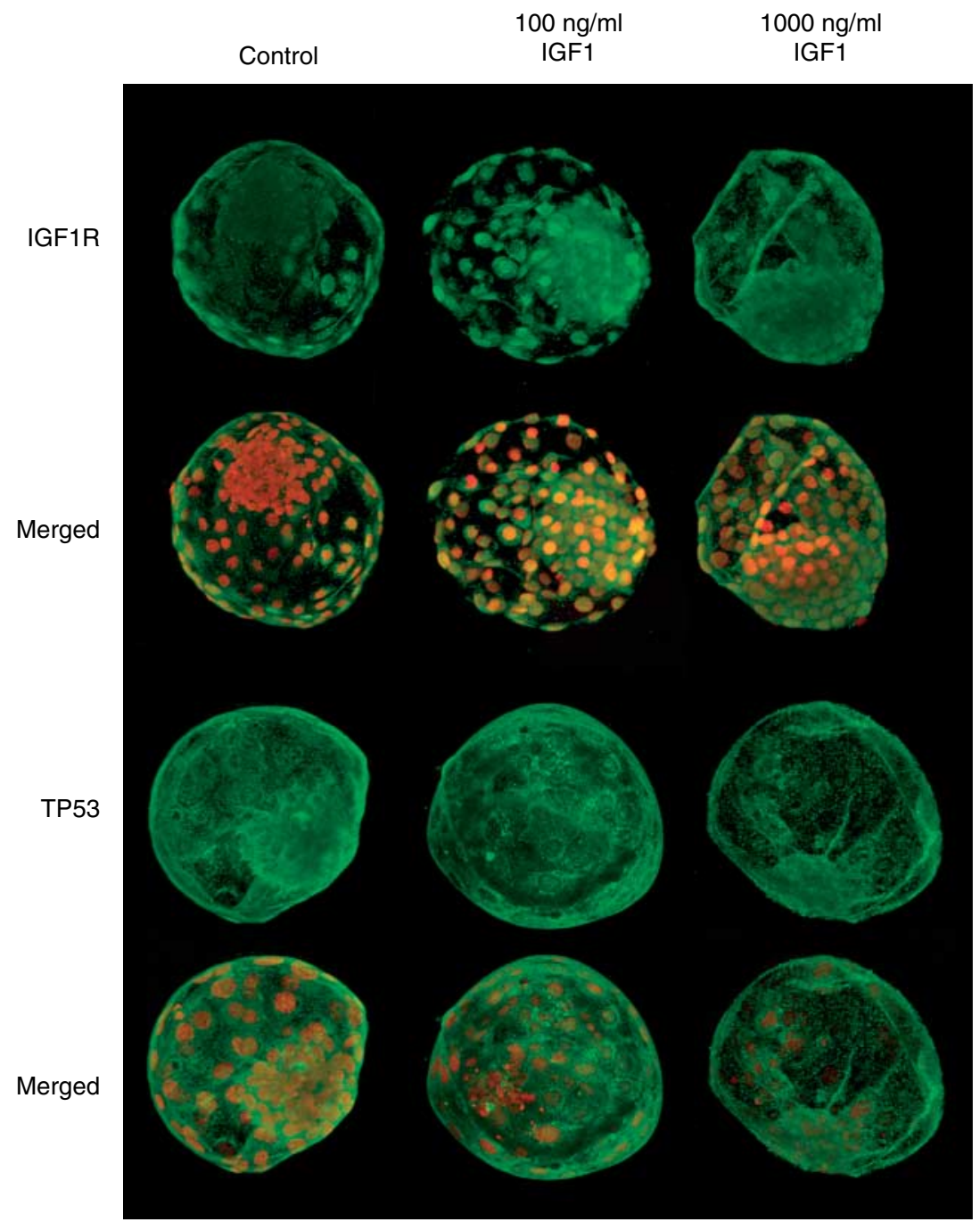

Figure 3 Three-dimensional reconstruction of confocal laser microscopy images showing protein localisation of the IGF1R and TP53 in day8 blastocysts cultured in the presence of different concentrations of IGF1. PI, propidium iodide. Note the lower expression of the IGF1R in the inner cell mass of the control group compared with the IGF1 groups and the lower expression of TP53 in the trophectoderm in the supraphysiological IGF1 group $(1000 \mathrm{ng} / \mathrm{ml})$. similar between the ICM and TE in the control group, whereas in the IGF1 groups TP53 immunofluorescence was less intense in the ICM (Fig. 5). RSS values of TP53 in the ICM were not affected by IGF1 treatment. TE RSS values of TP53 were not different between controls and physiological IGF1. However, embryos treated with $1000 \mathrm{ng} / \mathrm{ml}$ IGF1 had a decreased TP53 RSS in TE compared with the controls $(P=0.033)$ and treatment with $100 \mathrm{ng} / \mathrm{ml}$ IGF1 ( $P=0.048$ ). Supraphysiological IGF1 decreased total RSS compared with controls $(P=0.022)$ but not when compared with the physiological IGF1 group (Fig. 5). Total p53 RSS values were not different between the control and physiological IGF1 group. Total nuclei were not correlated with RSS values in any of the groups.

\section{Discussion}

The novel finding of this study is that the increased apoptosis in bovine blastocysts induced by supraphysiological IGF1 concentrations was not associated with downregulation of the IGF1R, as previously found for preimplantation murine embryos (Chi et al. 2000, Pinto et al. 2002, Eng et al. 2007). On the contrary, high levels of IGF1 increased IGF1R protein expression specifically in the ICM. Upregulation of IGF1R has been observed in bovine embryos cultured in the presence of $100 \mathrm{ng} / \mathrm{ml}$ Long R3 IGF1, which has a 1000-fold reduced affinity for IGFBPs (Prelle et al. 2001). The differential regulation of IGF1R during exposure to high levels of IGF1 could involve, yet unknown, signalling networks in the bovine embryo. For instance, IGF1 regulates expression of transcription factors such as Kruppel-like factor 6 (KLF6) in a TP53-dependent manner (Bentov et al. 2008). Its protein expression levels seem to be directly related to the protein levels of IGF1R (Rubinstein et al. 2004). KLF6 has been identified in murine embryonic cells (Laub et al. 2001) and is involved in murine embryonic stem (ES) cell differentiation (Matsumoto et al. 2008). KLF6 activates genes involved in cell proliferation and survival such as members of the transforming growth factor $\beta$ (TGFB) family, including the TGFB type III receptor (TGFBR3; Friedman et al. 


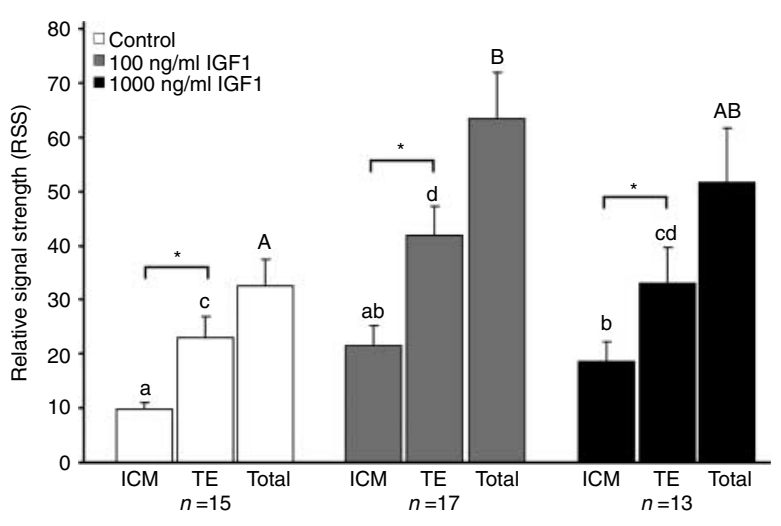

Figure 4 Relative signal strength (RSS) values (mean \pm S.E.M.) of the IGF1R in day-8 blastocysts treated with different concentrations of IGF1 and displaying immunofluorescence in the inner cell mass (ICM) and the trophectoderm (TE). Between groups, bars with different superscripts indicate a significant difference (ICM: a, b; TE: c, d; total RSS: A, $\mathrm{B} ; P \leq 0.05)$. Within groups, the asterisk indicates significant differences between the ICM and the TE $(P \leq 0.05)$.

2007). Accordingly, over-expression of TGFBR3 induces cellular apoptosis (Margulis et al. 2008). In this scenario, downregulation of the IGF1R would not be necessary to induce apoptosis. The TGFB signalling pathway is operative in both human (Adjaye et al. 2005) and bovine embryos (Huang et al. 2010). Interestingly, TGFB signalling pathway was associated with embryo demise, whereas TGFBR3 was upregulated in bovine embryos that did not complete the morula-to-blastocyst transition by day 8 after IVF (Huang et al. 2010).

Species-specific differences in embryonic IGF signalling could also account for the difference in regulation of IGF1R under high levels of IGF1 between mice and cattle. Gene expression of the IGF1 ligand has been detected from the zygote to the blastocyst stage in mouse embryos (Stojanov \& O'Neill 2001) and immunolocalisation studies confirmed its presence, revealing a higher expression in the ICM than in the TE cells (Stojanov \& O'Neill 2001). In contrast, early studies had reported the presence of mRNA for IGF1 ligand in preimplantation bovine embryos (Watson et al. 1992, Yoshida et al. 1998, Lonergan et al. 2000), but subsequent experiments did not confirm these observations (Yaseen et al. 2001, Bertolini et al. 2002, Ponsuksili et al. 2002, Moore et al. 2007, Warzych et al. 2007, Wang et al. 2009). This indicates an active autocrine IGF1 circuit in mice compared with cattle, similar to that of the ovary (Velazquez et al. 2008).

In rabbits (Herrler et al. 1997) and mice (Smith et al. 1993), the IGF1R is equally expressed in both the ICM and $T E$, although a recent study indicated that rabbit blastocysts expressed more IGF1R in the ICM than in the TE cells (Navarrete Santos et al. 2008). This differs from the low or lack of expression of IGF1R in the ICM of bovine blastocysts found in this study and by others (Wang et al. 2009). The lack of IGF1 production and the preferential expression of the IGF1R in the TE have also been observed in human embryos (Hardy \& Spanos 2002).

In this study, the higher ICM protein expression of the IGF1R observed in embryos treated with supraphysiological IGF1 concentrations corresponded with a specific increase in ICM cells. This is consistent with previous studies that showed a selective increase of cells in the ICM in bovine blastocysts (Sirisathien et al. 2003) and embryos from other species treated with IGF1, including humans (Lighten et al. 1998), pigs (Kim et al. 2005) and mice (Smith et al. 1993). The localised cell proliferation seems to be related to activation of the MAPK pathway in the ICM by IGF1 (Navarrete Santos et al. 2008). Nguyen et al. (2007) demonstrated that IGF1 can increase proliferation of mouse ES cells by stimulating protein synthesis via the MAPK pathway, similar to the situation observed in intact blastocysts (Navarrete Santos et al. 2008). Likewise, it has been found that IGF1R is co-localised with POU5F1 (Oct4) expression in human ES cells and plays a critical role for expansion of ES cell cultures as shown by the reduced cell number after IGF1R blocking (Bendall et al. 2007). The increase in IGF1R in the ICM was not translated into improved blastocyst formation, suggesting that IGF1 requires a simultaneous increase of its receptor in both cell compartments to exert beneficial effects upon bovine embryo development. Indeed, a more homogenous increase in IGF1R protein was detected in the group of embryos treated with physiological concentrations of IGF1, where increased blastocyst yields were found. This positive effect of IGF1 at physiological concentrations is probably related to improved glucose uptake via its own receptor (Pantaleon \& Kaye 1996) and could be due in part to a better modulation of IGF1 binding via higher expression of IGBPB3 observed in this and other studies (Prelle et al. 2001, Block et al. 2008).

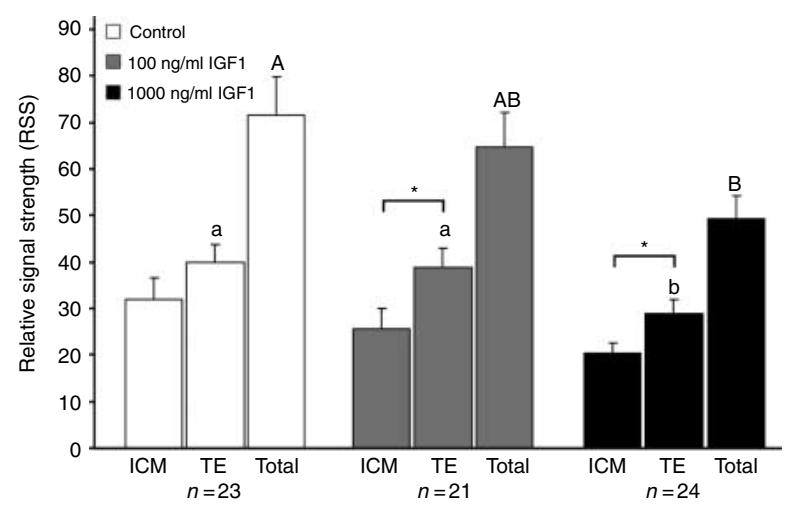

Figure 5 Relative signal strength (RSS) values (mean \pm s.E.M.) of TP53 in day-8 blastocysts treated with different concentrations of IGF1. ICM, inner cell mass; TE, trophectoderm. Between groups, bars with different superscripts indicate a significant difference (TE: a, b; total RSS: A, B; $P \leq 0.05)$. Within groups, the asterisk indicates significant differences between the ICM and the TE $(P \leq 0.05)$. 
The lower protein expression of TP53 in the supraphysiological IGF1 group was rather surprising since activation of TP53 is considered indicative of embryonic demise (Keim et al. 2001, Matwee et al. 2001). However, recent data suggest that TP53 does not act merely as a death signal, but rather as a modulator of damage responses to ensure successful development (Toyoshima 2009). It has been suggested that the primordial function of the TP53 ancestor gene was to ensure fecundity and production of normal offspring and that its function as a tumour suppressor came later in evolution (Hu 2009). Accordingly, there is evidence indicating that expression of TP53 is essential for female fertility (Hu et al. 2007) and that active TP53-dependent cell death signalling is required to suppress erroneous replication of damaged DNA during the preimplantation period (Toyoshima 2009) and to avoid abnormalities during foetal development (Torchinsky \& Toder 2010). In fact, high levels of TP53 are associated with regular cellular differentiation during murine embryogenesis (Schmid et al. 1991). From this perspective, we propose that the decrease in TP53 in embryos treated with high levels of IGF1 reflects a reduced capacity to eliminate unfit phenotypes, such as embryos with aberrant cell allocation.

Data from in vivo-produced bovine embryos indicate that an ICM/TCN proportion between 20 and $40 \%$ is within the normal range (Van Soom et al. 1997, Koo et al. 2002, Rho et al. 2007). In this study, a significant percentage of embryos treated with supraphysiological concentrations of IGF1 developed a high ICM/TCN proportion $(>40 \%)$. Control blastocysts did not exhibit this phenotype and it was practically absent in embryos treated with physiological concentrations of IGF1. A high ICM/TCN proportion $(41.3 \%)$ was found in experiments in which cysteine addition to the synthetic oviductal fluid (SOF) medium supplemented with foetal bovine serum increased apoptosis and reduced blastocyst formation and hatching rates (Van Soom et al. 2002). Furthermore, high ICM/TCN proportions $(42-60 \%)$ have been reported in bovine somatic cell nuclear transfer (SCNT) embryos (Koo et al. 2002, Amarnath et al. 2004, Li et al. 2004, 2007, Oh et al. 2006). The aberrant cell allocation of bovine SCNT embryos has been suggested to be partially responsible for the high embryonic losses occurring during early pregnancy (first trimester) after embryo transfer (KoO et al. 2002). We presume that the increased apoptosis observed mainly in the TE and the relative reduction in TE cell number caused by the high ICM/TCN proportion can give rise to either implantation failures or a foetus with impaired placental function with detrimental effects on pregnancy outcome. This hypothesis needs to be tested in embryo transfer studies.

Our data also indicate that the majority of embryos can cope with high concentrations of IGF1 and develop with a normal cell allocation. In our static in vitro system, consumption and degradation of IGF1 occurs without peptide renewal. In contrast, in a naturally occurring high IGF1 microenvironment such as with PCOS (Thierry van Dessel et al. 1999), the embryos are continuously exposed to abnormally high levels of IGF1, which may exacerbate the phenotype observed in our in vitro model (high apoptosis and hypertrophic ICM). Furthermore, given that oestrogens regulate to a great extent IGF1 production in the uterus (Velazquez et al. 2009), an increased paracrine action of IGF1 caused by the greater bioavailability of free oestrogens present in the endometrium of PCOS women (Leon et al. 2008) would lead to an impaired endometrial function (Lathi et al. 2002, Giudice 2006) that would further reduce chances of normal pregnancy.

Assuming that the bovine embryo resembles the human embryo behaviour in a high IGF1 microenvironment and that a concentration of $\sim 1000 \mathrm{ng} / \mathrm{ml}$ is present in the oviducts and uterus of PCOS women, we propose that a substantial proportion of embryos developing in a PCOS environment may adapt (i.e. do not undergo degeneration) to the high IGF1 levels and develop to the blastocyst stage with normal cell allocation but increased apoptosis. However, a small, but significant, proportion of embryos will develop a hypertrophic ICM. If endometrial function is impaired, embryos with hypertrophic ICM are less likely to implant and undergo normal placentation. If this holds true, the risk of pregnancy loss would be greater in a small percentage of PCOS women with hyperinsulinaemia. A recent survey showed that the prevalence of recurrent miscarriage in PCOS $(\sim 10 \%)$ women is relatively low (Cocksedge et al. 2009). However, our model assumes that oocyte quality is not seriously compromised, which probably is not the case, as oocyte developmental competence was reduced in a PCOS-like bovine model of hyperinsulinaemia (Adamiak et al. 2005). Furthermore, we have accumulated evidence that in vivo oocyte developmental competence can be impaired by high concentrations of IGF1 (MA Velazquez, K-G Hadeler, D Herrmann, WA Kues, S Ulbrich, HHD Meyer, B Rémy, J-F Beckers, H Sauerwein \& H Niemann 2010, unpublished data).

In conclusion, we have shown that supraphysiological concentrations of IGF1 have detrimental effects on preimplantation embryo development primarily by increasing apoptosis and altering cell allocation towards the ICM. However, our results do not support the premise that increased apoptosis associated with high levels of IGF1 is mediated via downregulation of the IGF1R as previously found in preimplantation mouse embryos. At present, we have no explanation for the observed apoptosis induction without IGF1R downregulation in bovine embryos exposed to a high IGF1 microenvironment. Cellular signalling networks can be affected by IGF1 in bovine embryos and species differences in IGF signalling could be promising to unravel this phenomenon. 


\section{Materials and Methods}

\section{Collection and maturation of cumulus-oocyte complexes}

Bovine ovaries from a local abattoir were transported to the laboratory at $25-30{ }^{\circ} \mathrm{C}$ in PBS (A0964; Applichem, Darmstadt, Germany), supplemented (enriched PBS) with $60 \mu \mathrm{g} / \mathrm{ml}$ penicillin G potassium (A1837, Applichem), $47 \mu \mathrm{g} / \mathrm{ml}$ streptomycin sulphate (A1852, Applichem), $36 \mu \mathrm{g} / \mathrm{ml}$ pyruvate (A3912, Applichem), $1.1 \mathrm{mg} / \mathrm{ml} \alpha$-D-glucose monohydrate (6780.1; Carl Roth GmbH, Karlsruhe, Germany) and $133 \mu \mathrm{g} / \mathrm{ml}$ calcium chloride dehydrate (21098; Fluka, SigmaAldrich). Ovaries were washed with $0.9 \%(\mathrm{w} / \mathrm{v})$ sodium chloride (3957.2, Carl Roth $\mathrm{GmbH}$ ) supplemented with $60 \mu \mathrm{g} / \mathrm{ml}$ penicillin $\mathrm{G}$ potassium and $1.3 \mu \mathrm{g} / \mathrm{ml}$ streptomycin sulphate. The surface of the ovaries was sliced in enriched PBS supplemented with $2.2 \mathrm{IU} / \mathrm{ml}$ heparin (24590; Serva, Heidelberg, Germany) and $0.1 \%(\mathrm{w} / \mathrm{v})$ BSA fraction V (A1391, Applichem). Cumulus-oocyte complexes (COCs) were collected in tissue culture medium (TCM) air (TCM 199, with Earle's salts, L-glutamine and 25 mM HEPES, M2520; SigmaAldrich) supplemented with $22 \mu \mathrm{g} / \mathrm{ml}$ pyruvate, $50 \mu \mathrm{g} / \mathrm{ml}$ gentamicin sulphate (G3632, Sigma-Aldrich), $350 \mu \mathrm{g} / \mathrm{ml}$ sodium bicarbonate $\left(\mathrm{NaHCO}_{3}, 31437\right.$; Sigma-Aldrich) and $0.1 \%(\mathrm{w} / \mathrm{v})$ BSA (fatty acid free, A7030; Sigma-Aldrich). Oocytes with at least three layers of compact cumulus cells and homogeneous granulated cytoplasm were selected (Racedo et al. 2008) and washed in groups of 15-20 in TCM culture medium (TCM air with a higher concentration of $\left.\mathrm{NaHCO}_{3}(2.2 \mathrm{mg} / \mathrm{ml})\right)$. COCs were then placed into $100 \mu \mathrm{l}$ drops of maturation medium (TCM culture supplemented with $10 \mathrm{IU} / \mathrm{ml}$ of equine chorionic gonadotrophin, $5 \mathrm{IU} / \mathrm{ml}$ of human chorionic gonadotrophin (Suigonan; Intervet, Unterschleißheim, Germany) and $100 \mu \mathrm{M}$ cysteamine hydrochloride (M6500, Sigma-Aldrich)) and were matured (in vitro maturation, IVM) under a humidified atmosphere of $5 \% \mathrm{CO}_{2}$ in air at $39^{\circ} \mathrm{C}$ for $24 \mathrm{~h}$.

\section{IVF}

The medium for IVF was Fert-TALP medium (Parrish et al. 1988) with some modifications, such as omission of glucose, supplementation with $0.1 \mathrm{IU} / \mathrm{ml}$ heparin, $0.01 \mu \mathrm{g} / \mathrm{ml}$ phenol red (Merck, Darmstadt, Germany) and a higher amount of sodium pyruvate $(28 \mu \mathrm{l} / \mathrm{ml})$. A basic stock solution of Fert-TALP medium without BSA (6 mg/ml, A9647, Sigma-Aldrich), gentamicin sulphate $(50 \mu \mathrm{g} / \mathrm{ml})$, sodium pyruvate, hypotaurine (10 $\mu \mathrm{M}, \mathrm{H1384}$; Sigma-Aldrich), heparin and epinephrine ( $1 \mu \mathrm{M}, \mathrm{E4250}$; Sigma-Aldrich) was prepared in advance. Matured COCs were washed with basic Fert-TALP medium supplemented with BSA, gentamicin sulphate and sodium pyruvate but lacking hypotaurine, heparin and epinephrine (HHE). The washed COCs were then placed in $100 \mu \mathrm{l}$ drops of Fert-TALP medium used for washing but supplemented with HHE (IVF drops). Semen of one bull of proven fertility for IVF was thawed at $30{ }^{\circ} \mathrm{C}$ and layered on top of $750 \mu \mathrm{l}$ of $90 \%(\mathrm{v} / \mathrm{v})$ Percoll/Fert-TALP solution (P1644, Sigma-Aldrich) equilibrated at room temperature in a 1.5 Eppendorf tube. After centrifugation $(400 \mathrm{~g})$ for $16 \mathrm{~min}$, the supernatant was aspirated and the pellet resuspended with $750 \mu$ of Fert-TALP without HHE. Centrifugation was applied again for $3 \mathrm{~min}$ followed by supernatant aspiration and pellet resuspension with Fert-TALP plus HHE. After a third 3 min centrifugation, the supernatant was aspirated leaving $\sim 50 \mu \mathrm{l}$ of sperm suspension. Sperm concentration was assessed and adjusted to $1 \times 10^{6} \mathrm{sperm} / \mathrm{ml}$, corresponding to $\sim 2 \mu \mathrm{l}$ sperm suspension per IVF drop. COCs were co-incubated with sperm for $18 \mathrm{~h}$ under the same grouping and atmospheric conditions used for IVM.

\section{In vitro culture}

The modified SOF medium described by Holm et al. (1999) without tri-sodium citrate but supplemented with $4 \mathrm{mg} / \mathrm{ml}$ fatty acid-free BSA (A7030, Sigma-Aldrich) was used for in vitro culture (IVC). After IVF, presumptive zygotes were denuded by gentle vortexing. Zygotes were then washed three times in $80 \mu \mathrm{l}$ drops of SOF medium followed by random allocation into $30 \mu \mathrm{l}$ drops of SOF medium without IGF1 (control group) or supplemented with either $100 \mathrm{ng} / \mathrm{ml}$ IGF1 (physiological concentration) or $1000 \mathrm{ng} / \mathrm{ml}$ IGF1 (supraphysiological concentration). In each replicate, 35-56 zygotes were used per group and the number of drops and embryos per drop (5-8 zygotes) was kept equal among the groups. For the IGF1 treatments, a vial containing $50 \mu \mathrm{g}$ of lyophilised recombinant human IGF1 (291-G1, R\&D systems, Wiesbaden-Norderstadt, Germany) was rehydrated with $500 \mu \mathrm{l}$ of $0.1 \%$ PBS/BSA according to the manufacturer's recommendations and stored at $-20{ }^{\circ} \mathrm{C}$ in $10 \mu \mathrm{l}$ aliquots (1000 ng). Culture drops containing IGF1 were prepared from two thawed aliquots diluted with SOF medium to the required concentrations of IGF1. Embryos were cultured in a humidified atmosphere containing $5 \% \mathrm{O}_{2}$, $5 \% \mathrm{CO}_{2}$ and $90 \% \mathrm{~N}_{2}$ (Air products, Hattingen, Germany) at $39{ }^{\circ} \mathrm{C}$. Drops used in each IVP cycle (i.e. IVM, IVF and IVC) were covered with silicone oil (35135, Silicone DC 200 fluid; Serva) and equilibrated for at least $3 \mathrm{~h}$ before use. Cleavage rate (embryos with four or more cells) and blastocyst formation were evaluated on days 3 and 8 after IVF (day 0) respectively. In each experimental group, cellular and molecular characteristics were evaluated only in day-8-expanded blastocysts obtained from 31 IVP cycles unless otherwise indicated.

\section{Differential cell staining}

Differential cell staining of blastocyst was carried out using a modified protocol described by Thouas et al. (2001). Briefly, zona-intact blastocysts were washed three times in $50 \mu \mathrm{l}$ drops of $0.1 \%(\mathrm{w} / \mathrm{v})$ polyvinylpyrrolidone/PBS and placed into $500 \mu \mathrm{l}$ of $1 \%(\mathrm{v} / \mathrm{v})$ Triton-X 100/PBS containing $100 \mu \mathrm{l} / \mathrm{ml}$ propidium iodide (PI) (P4170, Sigma-Aldrich) for $40 \mathrm{~s}$. Embryos were then transferred into $500 \mu \mathrm{l}$ of $100 \%$ ethanol containing $25 \mu \mathrm{l} / \mathrm{ml}$ bisbenzimide (Hoechst 33258, B 2883, Sigma-Aldrich) for 5 min. Blastocysts were mounted onto a glass microscope slide in an $\sim 4 \mu$ drop of glycerol and coverslipped. Cell counting was performed immediately after staining. Digital photographs of blastocysts were obtained with an epifluorescence microscope (Olympus BX60, Olympus Optical Co., Ltd, Tokyo, Japan) equipped with a digital camera (Olympus DP71) in a darkened room. Cell nuclei were counted using 
the touch-count mode of the Olympus cell ${ }^{\mathrm{P}}$ imaging software (Olympus Soft Imaging Solutions GmBH, Münster, Germany). Overlapping or out-of-focus nuclei in the digital photographs were identified by manual focus scanning of the samples under the microscope at the time of counting. Results are based on 11 IVP cycles.

\section{Detection of apoptosis by TUNEL}

Apoptotic nuclei were detected using an in situ cell death detection kit (Roche Diagnostics GmbH, Mannheim, Germany) based on the TUNEL principle using a previously described method (Zaraza et al. 2010). Briefly, zona-intact blastocysts were fixed in $4 \%(\mathrm{w} / \mathrm{v})$ paraformaldehyde/PBS solution for $1 \mathrm{~h}$ followed by permeabilisation with Triton X-100 solution $(0.5 \%$ (v/v) Triton X-100 in $0.1 \%(\mathrm{w} / \mathrm{v})$ sodium citrate/PBS) for $1 \mathrm{~h}$ at room temperature. Embryos were then incubated in $25 \mu \mathrm{l}$ drops of TUNEL reaction mixture ( $10 \mu$ l of terminal deoxynucleotidyl transferase (TdT) and $90 \mu$ of fluorescein-conjugated dUTP) for $1 \mathrm{~h}$ at $37^{\circ} \mathrm{C}$ in the dark. Positive and negative controls were incubated with RNA-free DNase I solution (50 U/ml, D9905K; Epicentre Biotechnologies, Madison, WI, USA) at $37^{\circ} \mathrm{C}$ for $1 \mathrm{~h}$ in the dark. After DNase incubation, positive controls were placed in the TUNEL reaction mixture and negative controls were incubated in the labelling solution in the absence of TdT. Thereafter, embryos were incubated in $50 \mu$ drops of RNase A solution $\left(50 \mu \mathrm{l} / \mathrm{ml}, \mathrm{R} 5500\right.$, Sigma-Aldrich) for $1 \mathrm{~h}$ at $37^{\circ} \mathrm{C}$ in the dark followed by nuclei counterstaining in $50 \mu \mathrm{l}$ drops of $\mathrm{PI}$ $(50 \mu \mathrm{l} / \mathrm{ml})$ for $15 \mathrm{~min}$ in the dark at room temperature. Blastocysts were then exposed to an increasing gradient (50, 75 and $100 \%$ ) of Vectashield antifade mounting medium/PBS (v/v, H-1000; Vector Laboratories, Burlingame, CA, USA) at room temperature in the dark and mounted individually in $100 \%$ Vectashield. Slides were stored at $4{ }^{\circ} \mathrm{C}$ in the dark for up to 7 days before confocal laser-scanning microscopy (CLSM) was performed. The embryos were subjected to CLSM with a Zeiss LSM 510 microscope (Carl Zeiss Microlmaging $\mathrm{GmbH}$, Göttingen, Germany) using a Plan-Apochromat 20×/0.75 objective. FITC (excitation wavelength at $488 \mathrm{~nm}$ ) and PI (excitation wavelength at $543 \mathrm{~nm}$ ) were detected with an argon and helium laser respectively. Optical sections of $1.98 \mu \mathrm{m}$ thickness were made at $4 \mu \mathrm{m}$ intervals through the whole embryo and analysed with the LSM Image Browser software (Carl Zeiss Microlmaging $\mathrm{GmbH}$ ). TCN and apoptotic nuclei were recorded. Nuclei were regarded as apoptotic only if they displayed both morphological (nuclear condensation with or without fragmentation) and biochemical (TUNEL positive) characteristics of apoptosis (Gjørret et al. 2003). Results are based on embryos obtained from eight IVP cycles.

\section{Immunofluorescence}

Zona-intact blastocysts from six IVP cycles were fixed and permeabilised as described in the TUNEL protocol. Following permeabilisation, embryos were blocked with $10 \%(\mathrm{v} / \mathrm{v})$ new born calf serum/PBS (B15-001; PAA Laboratories $\mathrm{GmbH}$, Pasching, Austria) for $1 \mathrm{~h}$ at room temperature followed by incubation overnight at $4{ }^{\circ} \mathrm{C}$ in the dark with the primary antibody diluted in 3\% (w/v) BSA/PBS (A9647, Sigma-Aldrich).
The TP53 antibody (rabbit polyclonal, 9282, Cell Signalling Technology, Inc., Danvers, MA, USA) was diluted 1:100 (Favetta et al. 2004) and the IGF1R (rabbit polyclonal, PAI14212; Dianova, Hamburg, Germany) 1:50. Embryos were then washed twice in Triton X-100 solution and incubated with the Alexa Fluor 488-conjugated secondary antibody $1: 100$ in $3 \%$ BSA/PBS; Invitrogen Ltd) for $2 \mathrm{~h}$ in the dark at room temperature. Embryos from the three groups were incubated in drops of equal volume obtained from the same antibody preparation. Later, embryos were treated with RNase, counterstained and mounted as described for the TUNEL protocol. Embryos not incubated with the primary antibody served as negative controls. Blastocysts were subjected to CLSM using the same settings as described in the TUNEL protocol. All embryos were scanned under the same confocal settings. Optical sections were analysed with LSM Image Browser software. After TCN counting, the fluorescence intensity of individual embryos was assessed in one central optical section displaying both the ICM and the TE by marking and extracting six small areas of equal size. Extracted images were saved in tagged image file format (TIFF) and processed according to the method developed by Tolivia et al. (2006) and validated in bovine embryos (Favetta et al. 2007). Briefly, green channel images (representing Alexa Fluor 488 fluorescence) were converted to 'greyscale' and then inverted with Adobe Photoshop CS2 (Adobe Systems Inc.) so that grey and black pixels represented the areas of Alexa Fluor 488 immunofluorescence on a white background. Inverted images were saved as a new TIFF file and opened in the Scion Image program (4.0.3.2, Scion Corporation, Frederick, MD, USA) to obtain the mean density of the chromogen signal strength (SS). The SS was normalised to the maximum SS obtained in each image in order to produce a relative SS (Tolivia et al. 2006). The relative SS in individual embryos was the mean value of the small sections extracted per embryo (i.e. six for the whole embryo and three per cell compartment (ICM and TE)).

\section{mRNA isolation}

Blastocysts from six IVP cycles were individually placed into $0.6 \mathrm{ml}$ siliconised Eppendorf tubes with $\sim 4 \mu \mathrm{l}$ of $0.1 \%$ (w/v) polyvinyl alcohol/PBS solution and stored at $-80^{\circ} \mathrm{C}$ until mRNA extraction. Poly $(\mathrm{A})^{+}$RNA was isolated using a Dynabeads mRNA DIRECT micro kit (610.21, Invitrogen Dynal AS) with some modifications to the manufacture's instructions as previously described (Kues et al. 2008, Niemann et al. 2010). Briefly, $40 \mu \mathrm{l}$ of lysis-binding buffer (100 mM Tris$\mathrm{HCl}, \mathrm{pH} 7.5,500 \mathrm{mM} \mathrm{LiCl}, 10 \mathrm{mM}$ EDTA, 1\% lithium dodecyl sulphate (LiDS), $5 \mathrm{mM}$ dithiothreitol) were pipetted into each sample tube, followed by addition of 1 pg rabbit globin mRNA (Bethesda Research Laboratories, Gaithersburg, MD, USA) as external standard. After a short centrifugation, samples were incubated at room temperature for $10 \mathrm{~min}$. In all, $5 \mu \mathrm{l}$ of prewashed Dynabeads Oligo $(\mathrm{dT})_{25}$ were then added into each lysate and placed on a shaker at room temperature for $15 \mathrm{~min}$ to allow binding of the poly (A) ${ }^{+}$RNA to the Dynabeads. The beads were then washed once with $40 \mu$ l buffer A (10 mM Tris$\mathrm{HCl}, \mathrm{pH}$ 8.0, 0.15 M LiCl, $1 \mathrm{mM}$ EDTA, 0.1\% LiDS) and three times with $40 \mu \mathrm{l}$ buffer B $(10 \mathrm{mM}$ Tris- $\mathrm{HCl}, \mathrm{pH} 8.0,0.15 \mathrm{M}$ 
LiCl, $1 \mathrm{mM}$ EDTA) at room temperature. After washing, beads were resuspended with $11 \mu \mathrm{l}$ ice-cold sterile water and the poly $(\mathrm{A})^{+}$RNAs were eluded from the beads by incubation at $65{ }^{\circ} \mathrm{C}$ for $2.5 \mathrm{~min}$ followed by flash cooling on ice. The $11 \mu$ l elution aliquots were used immediately for RT.

\section{RT}

Poly $(\mathrm{A})^{+}$RNA from single blastocysts was reverse transcribed into first strand $\mathrm{CDNA}$ in a $0.2 \mathrm{ml}$ reaction tube containing $20 \mu \mathrm{l}$ reaction mixture. The RT reaction mixture consisted of $2 \mu \mathrm{l}(1 \times, 20 \mathrm{mM}$ Tris- $\mathrm{HCl}, \mathrm{pH} 8.4,50 \mathrm{mM} \mathrm{KCl})$ of $10 \times \mathrm{RT}$ buffer (Invitrogen), $2 \mu \mathrm{l}(5 \mathrm{mM})$ of magnesium chloride (Invitrogen, Karlsruhe, Germany), $2 \mu \mathrm{l}(1 \mathrm{mM})$ of dNTP solution (Amersham Biosciences Europe), $1 \mu \mathrm{l}(2.5 \mu \mathrm{M})$ of random hexamer primers (N808-0017, GeneAmp RNA PCR kit; Applied Biosystems, Darmstadt, Germany), $1 \mu$ l (20 U) of RNase inhibitor (N808-0119, Applied Biosystems), $1 \mu \mathrm{l}$ (50 U) of murine leukaemia virus reverse transcriptase (N8080018, Applied Biosystems) and the $11 \mu \mathrm{l}$ of mRNA preparation. Tubes with reaction mixture containing sterile water instead of mRNA preparation were used as controls for contamination. A tube with reaction mixture and $2 \mu \mathrm{l}(1 \mathrm{pg})$ of rabbit globin mRNA and $9 \mu \mathrm{l}$ of sterile water was prepared to produce a pool of cDNA globin for quantification of globin expression used for data normalisation (see below). The RT reaction was carried out in a PTC-200 thermocycler (MJ Research, Watertown, MA, USA) and consisted of $10 \mathrm{~min}$ at $25^{\circ} \mathrm{C}$ for primer annealing, $1 \mathrm{~h}$ at $42{ }^{\circ} \mathrm{C}$ for primer extension and $5 \mathrm{~min}$ at $95^{\circ} \mathrm{C}$ to terminate the reaction followed by cooling down at $8{ }^{\circ} \mathrm{C}$ and storage at $-25{ }^{\circ} \mathrm{C}$ until real-time PCR analysis.

\section{Quantitative real-time PCR}

For real-time PCR, wells from 96-well optical reaction plates were loaded with $20 \mu \mathrm{I}$ PCR reaction mixture containing $10 \mu \mathrm{l}$ power SYBR green PCR master mix (4367659, Applied Biosystems), $0.8 \mu \mathrm{l}(5 \mu \mathrm{M})$ each of the forward and reverse primers of the respective genes of interest (Table 3), $2 \mu \mathrm{l}$ cDNA (0.2 blastocyst equivalents) and $6.4 \mu \mathrm{l}$ sterile water. Amplification was carried out in an ABI 7500 Fast Real-Time System (Applied Biosystems). The PCR reaction started with $10 \mathrm{~min}$ at $95^{\circ} \mathrm{C}$ for activation of the Taq DNA Polymerase, followed by 40 cycles of $15 \mathrm{~s}$ at $95^{\circ} \mathrm{C}$ for denaturation and $1 \mathrm{~min}$ at $60^{\circ} \mathrm{C}$ for annealing and extension. Post PCR, dissociation melting curve analyses were carried out to determine the specificity of the PCR-amplified products. Raw gene expression data for target genes and globin were obtained with the Sequence Detection Software 1.3.1 (Applied Biosystems) based on standard curve dilution series (1:5) of cDNA from 60 blastocysts and pooled globin respectively (Niemann et al. 2010). Data were then transferred to Microsoft excel and the relative mRNA abundance was calculated by dividing the target gene expression value by the amount of globin mRNA expressed in each sample (globin added as external control during RNA extraction). To normalise data to embryo cell number, the relative abundance of each transcript in individual embryos was divided by the mean TCN (Table 2) and multiplied by 100 (Block et al. 2008). For each group, results are based on 12 replicates per gene.

\section{Statistical analysis}

Data were analysed with SigmaStat 2.0 (Jandel Scientific, San Rafael, CA, USA). Differences between the groups were tested by $\chi^{2}$ test and ANOVA with the Fisher's least significant difference method as post hoc test. Associations between variables were tested by regression analysis. Percentage values analysed as continous data were arcsine transformed before analysis. Continous data were transformed if they did not meet the assumption of normal distribution or homogeneity of variance. If no improvement was achieved after transformation, non-parametric equivalents were used (e.g. the Kruskal-Wallis test). When a $P$ value with a tendency towards significance $(<0.08)$ was detected with ANOVA or the Kruskal-Wallis test, a two-group comparison test was carried out (e.g. Student's $t$-test) to clarify the differences between treatments. Fluorescence intensity within the groups (i.e. ICM versus TE) was analysed by $t$-test or the Mann-Whitney test as appropriate. Since data were analysed by parametric and non-parametric tests, results are presented as mean \pm S.E.M. and median (Q1-Q3) unless otherwise indicated. $P \leq 0.05$ was considered to be statistically significant.

Table 3 Primers used for real-time PCR.

\begin{tabular}{|c|c|c|c|c|c|}
\hline \multirow{3}{*}{$\frac{\text { Genes }}{I G F 1 R}$} & \multicolumn{2}{|c|}{ Primer sequences and positions } & \multirow{3}{*}{$\begin{array}{c}\begin{array}{c}\text { Annealing } \\
\text { temperature }\left({ }^{\circ} \mathrm{C}\right)\end{array} \\
60\end{array}$} & \multirow{2}{*}{$\begin{array}{c}\begin{array}{c}\text { Fragment } \\
\text { size }(b p)\end{array} \\
72\end{array}$} & \multirow{3}{*}{$\begin{array}{c}\begin{array}{c}\text { Accession } \\
\text { number }\end{array} \\
X M \_606794.3\end{array}$} \\
\hline & $5^{\prime}(1068-1090)$ & ССТСАTСAGСТTСАССGТСТАСТ & & & \\
\hline & $3^{\prime}(1139-1121)$ & GCGTCCTGCCCGTCATACT & & & \\
\hline \multirow[t]{2}{*}{ IGFBP3 } & $5^{\prime}(731-752)$ & AАСТTСТССТСТGAGTCCAAGC & 60 & 210 & NM_174556.1 \\
\hline & $3^{\prime}(941-921)$ & CGTACTTATCCACACACCAGC & & & \\
\hline \multirow[t]{2}{*}{ TP53 } & $5^{\prime}(720-739)$ & TTTACGCGCGGAGTATTTGG & 60 & 57 & NM_174201.2 \\
\hline & $3^{\prime}(776-756)$ & GGCACCACCACACTGTGTCTA & & & \\
\hline \multirow[t]{2}{*}{$A K T 1$} & $5^{\prime}(368-385)$ & GCTCACCCGGCGAGAACT & 60 & 108 & AY781100.1 \\
\hline & $3^{\prime}(457-475)$ & CTTTGCCCAGCAGCTTCAG & & & \\
\hline \multirow[t]{2}{*}{$S L C 2 A 1$} & $5^{\prime}(894-914)$ & CAGGAGATGAAGGAGGAGAGC & 60 & 258 & NM_174602.2 \\
\hline & $3^{\prime}(1131-1151)$ & CACAAATAGCGACACGACAGT & & & \\
\hline \multirow[t]{2}{*}{$S L C 2 A 3$} & $5^{\prime}(127-149)$ & GTTGCTACCATAGGCTCTTTCCA & 60 & 65 & AY033938 \\
\hline & $3^{\prime}(173-192)$ & GATCGCCTCAGGAGCATTGA & & & \\
\hline \multirow[t]{2}{*}{$S L C 2 A 8$} & $5^{\prime}(1441-1461)$ & GCATCTTCGGTGTCCTTTTCA & 60 & 80 & AY208940 \\
\hline & $3^{\prime}(1501-1521)$ & CAAAATGGGCTGTGATTTGCT & & & \\
\hline
\end{tabular}




\section{Declaration of interest}

The authors declare that there is no conflict of interest that could be perceived as prejudicing the impartiality of the research reported.

\section{Funding}

M A Velazquez was supported by the German Academic Exchange Service (DAAD).

\section{Acknowledgements}

M A Velazquez was in the PhD programme of the University of Veterinary Medicine, Hannover, Germany.

\section{References}

Adamiak SJ, Mackie K, Watt RG, Webb R \& Sinclair KD 2005 Impact of nutrition on oocyte quality: cumulative effects of body composition and diet leading to hyperinsulinemia in cattle. Biology of Reproduction $\mathbf{7 3}$ 918-926. (doi:10.1095/biolreprod.105.041483)

Adjaye J, Huntris J, Herwig R, Benkahla A, Brink TC, Wierling C, Hultsching C, Groth D, Yaspo M-L, Picton HM et al. 2005 Primary differentiation in the human blastocysts: comparative molecular portraits of inner cell mass and trophectoderm cells. Stem Cells 23 1514-1525. (doi:10.1634/stemcells.2005-0113)

Adjaye J, Herwig R, Brink TC, Herrmann D, Greber B, Sudheer S, Groth D, Carnwath JW, Lehrach H \& Niemann H 2007 Conserved molecular portraits of bovine and human blastocysts as a consequence of the transition from maternal to embryonic control of gene expression. Physiological Genomics 31 315-327. (doi:10.1152/physiolgenomics. 00041.2007)

Amarnath D, Kato Y \& Tsunoda Y 2004 Cryopreservation of bovine somatic cell nuclear-transferred blastocysts: effect of developmental stage. Journal of Reproduction and Development 50 593-598. (doi:10.1262/ jrd.50.593)

Baumann CG, Morris DG, Sreenan JM \& Leese HJ 2007 The quiet embryo hypothesis: molecular characteristics favoring viability. Molecular Reproduction and Development 74 1345-1353. (doi:10.1002/mrd. 20604)

Bendall SC, Steward MH, Menendez P, George D, Vijayaragavan K, Werbowetski-Ogilvie T, Ramos-Mejia V, Rouleau A, Yang J, Bossé M et al. 2007 IGF and FGF cooperatively establish the regulatory stem cell niche of pluripotent human cells in vitro. Nature 448 1015-1021. (doi:10.1038/nature06027)

Benito M, Valverde AM \& Lorenzo M 1996 IGF-1: a mitogen also involved in differentiation processes in mammalian cells. International Journal of Biochemistry and Cell Biology 28 499-510. (doi:10.1016/13572725(95)00168-9)

Bentov I, Narla G, Schayek H, Akita K, Plymate SR, LeRoith D, Friedman SL \& Werner H 2008 Insulin-like growth factor-I regulates Krüppel-like factor-6 gene expression in a p53-dependant manner. Endocrinology 149 1890-1897. (doi:10.1210/en.2007-0844)

Bertolini M, Beam SW, Shim H, Bertolini LR, Moyer AL, Famula TR \& Anderson GB 2002 Growth, development, and gene expression by in vivo- and in vitro-produced day 7 and 16 bovine embryos. Molecular Reproduction and Development 63 318-328. (doi:10.1002/ mrd.90015)

Block J \& Hansen PJ 2007 Interaction between season and culture with insulin-like growth factor- 1 on survival of in vitro produced embryos following transfer to lactating dairy cows. Theriogenology 67 1518-1529. (doi:10.1016/j.theriogenology.2007.03.012)

Block J, Drost M, Monson RL, Rutledge JJ, Rivera RM, Paula-Lopes FF, Ocon OM, Krininger CE III, Liu J \& Hansen PJ 2003 Use of insulin-like growth factor-I during embryo culture and treatment of recipients with gonadotropin-releasing hormone to increase pregnancy rates following the transfer of in vitro-produced embryos to heat-stressed, lactating cows. Journal of Animal Science 81 1590-1602.

Block J, Wrenzycki C, Niemann H, Herrmann D \& Hansen P 2008 Effects of insulin-like growth factor- 1 on cellular and molecular characteristics of bovine blastocysts produced in vitro. Molecular Reproduction and Development 75 895-903. (doi:10.1002/mrd.20826)

Byrne AT, Southgate J, Brison DR \& Leese HJ 2002 Regulation of apoptosis in the bovine blastocyst by insulin and insulin-like growth factor (IGF) superfamily. Molecular Reproduction and Development 62 489-495. (doi:10.1002/mrd.10153)

Chi MM, Schlein AL \& Moley KH 2000 High insulin-like growth factor 1 (IGF-1) and insulin concentrations trigger apoptosis in the mouse blastocyst via down-regulation of the IGF-1 receptor. Endocrinology 141 4784-4792. (doi:10.1210/en.141.12.4784)

Cocksedge KA, Li TC, Saravelos SH \& Metwally M 2008 A reappraisal of the role of polycystic ovary syndrome in recurrent miscarriage. Reproductive Biomedicine Online 17 151-160. (doi:10.1016/S1472-6483(10)60304-5)

Cocksedge KA, Saravelos SH, Metwally M \& Li TC 2009 How common is polycystic ovary syndrome in recurrent miscarriage. Reproductive Biomedicine Online 19 572-576. (doi:10.1016/j.rbmo.2009.06.003)

Eng GS, Sheridan RA, Wyman A, Chi MMY, Bibee KP, Jungheim ES \& Moley KH 2007 AMP kinase activation increases glucose uptake, decreases apoptosis, and improves pregnancy outcome in embryos exposed to high IGF-I concentrations. Diabetes 56 2228-2234. (doi:10. 2337/db07-0074)

Essah PA, Cheang KI \& Nestler JE 2004 The pathophysiology of miscarriage in women with polycystic ovary syndrome. Review and proposed hypothesis of mechanisms involved. Hormones 3 221-227.

Favetta LA, Robert C, St John EJ, Betts DH \& King WA 2004 p $66^{\text {shc }}$, but not p53, is involved in early arrest of in vitro-produced bovine embryos. Molecular Human Reproduction 10 383-392. (doi:10.1093/molehr/ gah057)

Favetta LA, Madan P, Mastromonaco GF, St John EJ, King WA \& Betts DH 2007 The oxidative stress adaptor p66Shc is required for permanent embryo arrest in vitro. BMC Developmental Biology 7 132. (doi:10. 1186/1471-213X-7-132)

Francis GL, Upton FM, Ballard FJ, McNeil KA \& Wallace JC 1988 Insulinlike growth factors 1 and 2 in bovine colostrum. Biochemical Journal 251 95-103.

Friedman SL, Narla G \& Martignetti JA 2007 KLF6 (Krüppel like factor 6). Atlas of Genetics and Cytogenetics in Oncology and Haematology, URL: http://AtlasGeneticsOncology.org/Genes/KLF6ID44002ch10p15.html.

Giudice LC 2006 Endometrium in PCOS. Implantation and predisposition to endocrine CA. Best Practice and Research. Clinical Endocrinology and Metabolism 20 235-244. (doi:10.1016/j.beem.2006.03.005)

Gjørret JO, Knijn HM, Dieleman SJ, Avery B, Larsson LI \& MaddoxHyttel P 2003 Chronology of apoptosis in bovine embryos produced in vivo and in vitro. Biology of Reproduction 69 1193-1200. (doi:10.1095/ biolreprod.102.013243)

Głabowski W, Kurzawa R, Wiszniewska B, Bęczkowski T, Marchlewicz M \& Brelik P 2005 Growth factors effects on preimplantation development of mouse embryos exposed to tumor necrosis factor alpha. Reproductive Biology 5 83-99.

Hardy K \& Spanos S 2002 Growth factor expression and function in the human and mouse preimplantation embryo. Journal of Endocrinology 172 221-236. (doi:10.1677/joe.0.1720221)

Herrler A, Einspanier R \& Beier HM 1997 Binding of IGF-I to preimplantation rabbit embryos and their coats. Theriogenology $\mathbf{4 7}$ 1595-1607. (doi:10.1016/S0093-691X(97)00164-7)

Herrler A, Krusche CA \& Beier HM 1998 Insulin and insulin-like growth factor-I promote rabbit blastocyst development and prevent apoptosis. Biology of Reproduction 59 1302-1310. (doi:10.1095/biolreprod59.6. 1302)

Holm P, Booth PJ, Schmidt MH, Greve T \& Callesen H 1999 High bovine blastocyst development in a static in vitro production system using SOFaa medium supplemented with sodium citrate and myo-inositol with or without serum proteins. Theriogenology 52 683-700. (doi:10.1016/ S0093-691X(99)00162-4)

Honegger A \& Humbel RE 1986 Insulin-like growth factors I and II in fetal and adult bovine serum. Purification, primary structures, and immunological cross-reactivities. Journal of Biological Chemistry 261 569-575. 
Hu W 2009 The role of p53 gene family in reproduction. Cold Spring Harbor Perspectives in Biology 1 a001073. (doi:10.1101/cshperspect. a001073)

Hu W, Feng Z, Teresky AK \& Levine AJ 2007 p53 regulates maternal reproduction through LIF. Nature 450 721-724. (doi:10.1038/ nature05993)

Huang W, Yandell BS \& Khatib H 2010 Transcriptomic profiling of bovine IVF embryos revealed candidate genes and pathways involved in early embryonic development. BMC Genomics 11 23. (doi:10.1186/14712164-11-23)

Inzunza J, Danielsson O, Latitkumar PG, Larsson O, Axelson M, Töhönen V, Danielsson KG \& Stavreus-Evers A 2010 Selective insulinlike growth factor-I antagonist inhibits mouse embryo development in a dose dependant manner. Fertility and Sterility 93 2621-2626. (doi:10. 1016/j.fertnstert.2009.12.044)

Jousan FD \& Hansen PJ 2007 Insulin-like growth factor-I promotes resistance of bovine preimplantation embryos to heat shock through actions independent of its anti-apoptotic actions requiring $\mathrm{PI} 3 \mathrm{~K}$ signaling. Molecular Reproduction and Development 74 189-196. (doi:10.1002/mrd.20527)

Katagiri S, Moon YS \& Yuen BH 1996 The role for the uterine insulin-like growth factor I in early embryonic loss after superovulation in the rat. Fertility and Sterility 65 426-436.

Katagiri S, Ma S, Yuen BH \& Moon YS 1997 Role for insulin-like growth factor $\mathbf{I}$ in the regulation of electrolyte composition of uterine luminal fluid. Journal of Reproduction and Fertility 109 115-120. (doi:10.1530/ jrf.0.1090115)

Keim AL, Chi MMY \& Moley KH 2001 Hyperglycemia-induced apoptotic cell death in the mouse blastocyst is dependant on expression of p53. Molecular Reproduction and Development 60 214-224. (doi:10.1002/ mrd.1080)

Kim S, Lee GS, Lee SH, Kim HS, Jeong YW, Kim JH, Kang SK, Lee BC \& Hwang WS 2005 Embryotropic effect of insulin-like growth factor (IGF)-I and its receptor on development of porcine preimplantation embryos produced by in vitro fertilization and somatic cell nuclear transfer. Molecular Reproduction and Development 72 88-97. (doi:10.1002/mrd. 20327)

Kim S, Lee SH, Kim JH, Jeong YW, Hashem MA, Koo OJ, Park SM, Lee EG, Hossein MS, Kang SK et al. 2006 Anti-apoptotic effect of insulin-like growth factor (IGF)-I and its receptor in porcine preimplantation embryos derived from in vitro fertilization and somatic cell nuclear transfer. Molecular Reproduction and Development 73 1523-1530. (doi:10. 1002/mrd.20531)

Koo DB, Kang Y-K, Choi YH, Park JS, Kim HN, Oh KB, Son DS, Park H, Lee KK \& Han YM 2002 Aberrant allocations of inner cell mass and trophectoderm cells in bovine nuclear transfer blastocysts. Biology of Reproduction 67 487-492. (doi:10.1095/biolreprod67.2.487)

Kues WA, Sudheer S, Herrmann D, Carnwath JW, Havlicek V, Besenfelder U, Lehrach H, Adjaye J \& Niemann H 2008 Genomewide expression profiling reveals distinct clusters of transcriptional regulation during bovine preimplantation development in vivo. PNAS 105 19768-19773. (doi:10.1073/pnas.0805616105)

Lathi RB, Swiersz L, Basina M \& Giudice LC 2002 The endometrium in polycystic ovary syndrome. Current Opinion in Endocrinology and Diabetes 9 480-485. (doi:10.1097/00060793-200212000-00007)

Laub F, Aldabe R, Ramirez F \& Friedman S 2001 Embryonic expression of krüppel-like factor 6 in neural and non-neural tissues. Mechanisms of Development 106 167-170. (doi:10.1016/S0925-4773(01)00419-1)

Leon L, Bacallao K, Gabler F, Romero C, Valladares L \& Vega M 2008 Activities of steroid metabolic enzymes in secretory endometria from untreated women with polycystic ovary syndrome. Steroids 73 88-95. (doi:10.1016/j.steroids.2007.09.003)

Li GP, Bunch TD, White KL, Aston KI, Meerdo LN, Pate BJ \& Sessions BR 2004 Development, chromosomal composition, and cell allocation of bovine cloned blastocyst derived from chemically assisted enucleation and cultured in conditioned media. Molecular Reproduction and Development 68 189-197. (doi:10.1002/mrd.20071)

Li Y, Li S, Dai Y, Du W, Zhao C, Wang L, Wang H, Li R, Liu Y, Wan R et al. 2007 Nuclear reprogramming in embryos generated by the transfer of yak (Bos grunniens) nuclei into bovine oocytes and comparison with bovine-bovine SCNT and bovine IVF embryos. Theriogenology 67 1331-1338. (doi:10.1016/j.theriogenology.2006.10.022)
Lighten AD, Hardy K, Winston RML \& Moore GE 1997 Expression of mRNA for the insulin-like growth factors and their receptors in human preimplantation embryos. Molecular Reproduction and Development 47 134-139. (doi:10.1002/(SICl)1098-2795(199706)47:2 < 134::AIDMRD2 > 3.0.CO;2-N)

Lighten AD, Moore GE, Winston RML \& Hardy K 1998 Routine addition of human insulin-like growth factor-I ligand could benefit clinical in-vitro fertilization culture. Human Reproduction 13 3144-3150. (doi:10.1093/ humrep/13.11.3144)

Lin TC, Yen JM, Gong KB, Hsu TT \& Chen R 2003 IGF-1/IGFBP-1 increases blastocysts formation and total blastocyst cell number in mouse embryo culture and facilitates the establishment of a stem cell line. BMC Cell Biology 4 14. (doi:10.1186/1471-2121-4-14)

Lonergan P, Gutierrez-Adan A, Pintado B, Fair T, Ward F, Fuente JD \& Boland M 2000 Relationship between time of first cleavage and the expression of IGF-I growth factor, its receptor, and two housekeeping genes in bovine two-cell embryos and blastocysts produced in vitro. Molecular Reproduction and Development 57 146-152. (doi:10.1002/ 1098-2795(200010)57:2 < 146::AID-MRD5 > 3.0.CO;2-2)

Louden E, Chi MM \& Moley KH 2008 Crosstalk between the AMP-activated kinase and insulin signalling pathways rescues murine blastocyst cells from insulin resistance. Reproduction 136 335-344. (doi:10.1530/REP-08-0161)

Makarevich AV \& Markkula M 2002 Apoptosis and cell proliferation potential of bovine embryos stimulated with insulin-like growth factor I during in vitro maturation and culture. Biology of Reproduction 66 386-392. (doi:10.1095/biolreprod66.2.386)

Margulis V, Maity T, Zhang XY, Cooper SJ, Copland JA \& Wood CG 2008 Type III transforming growth factor- $\beta$ (TGF- $\beta$ ) receptor mediates apoptosis in renal cell carcinoma independent of the canonical TGF- $\beta$ signaling pathway. Clinical Cancer Research 14 5722-5730. (doi:10. 1158/1078-0432.CCR-08-0546)

Markham KE \& Kaye PL 2003 Growth hormone, insulin-like growth factor I and cell proliferation in the mouse blastocyst. Reproduction 125 327-336. (doi:10.1530/rep.0.1250327)

Matsumoto N, Zhao X, Itoh F \& Friedmann SL 2008 Divergent roles of tumor suppressor gene KIf6 in ES cell differentiation. Journal of Electrophoresis 52 65-69. (doi:10.2198/jelectroph.52.65)

Matwee C, Kamaruddin M, Betts DH, Basrur PK \& King AW 2001 The effects of antibodies to heat shock protein 70 in fertilization and embryo development. Human Reproduction 7 829-837. (doi:10.1093/molehr/ 7.9.829)

Ménézo YJ \& Hérubel F 2002 Mouse and bovine models for human IVF. Reproductive Biomedicine Online 4 170-175. (doi:10.1016/S14726483(10)61936-0)

Moley KH, Bibee K, Wyman A \& Eng GS 2005 IGF-1 induced blastocyst apoptosis is p53 dependant. Fertility and Sterility 84388 (abstract). (doi:10.1016/j.fertnstert.2005.07.1015)

Moore K, Kramer JM, Rodriguez-Sallaberry CJ, Yelich JV \& Drost M 2007 Insulin-like growth factor (IGF) family genes are aberrantly expressed in bovine conceptuses produced in vitro or by nuclear transfer. Theriogenology 68 717-727. (doi:10.1016/j.theriogenology.2007.06.001)

Narula A, Taneja M \& Totey SM 1996 Morphological development, cell number, and allocation of cells to trophectoderm and inner cell mass of in vitro fertilized and parthenogenetically developed buffalo embryos: the effect of IGF-1. Molecular Reproduction and Development 44 343-351. (doi:10.1002/(SICI)1098-2795(199607)44:3<343::AIDMRD8 > 3.0.CO;2-M)

Navarrete Santos A, Ramin N, Tonack S \& Fischer B 2008 Cell lineagespecific signaling of insulin and insulin-like growth factor $\mathrm{I}$ in rabbit blastocysts. Endocrinology 149 515-524. (doi:10.1210/en.2007-0821)

Nguyen TT, Sheppard AM, Kaye PL \& Noakes PG 2007 IGF-I and insulin activate mitogen-activated protein kinase via the type 1 IGF receptor in mouse embryonic cells. Reproduction 134 41-49. (doi:10.1530/REP-060087)

Niemann H, Carnwath JW, Herrmann D, Wieczoreck G, Lemme E, LucasHahn A \& Olek S 2010 DNA methylation patterns reflect epigenetic reprogramming in bovine embryos. Cellular Reprogramming 12 33-42. (doi:10.1089/cell.2009.0063)

Oh BC, Kim JT, Shin NS, Kwon SW, Kang SK, Lee BC \& Hwang WS 2006 Production of blastocysts after intergeneric nuclear transfer of Goral (Naemorhedus goral) somatic cells into bovine oocytes. Journal of Veterinary Medical Science 68 1167-1171. (doi:10.1292/jvms.68.1167) 
Pantaleon M \& Kaye PL 1996 IGF-I and insulin regulate glucose transport in mouse blastocysts via IGF-I receptor. Molecular Reproduction and Development 44 71-76. (doi:10.1002/(SICI)1098-2795(199605) 44:1<71::AID-MRD8>3.0.CO;2-Q)

Parrish JJ, Susko-Parrish J, Winer MA \& First NL 1988 Capacitation of bovine sperm by heparin. Biology of Reproduction 38 1171-1180. (doi:10.1095/biolreprod38.5.1171)

Pinto AB, Schlein AL \& Moley KH 2002 Preimplantation exposure to high insulin-like growth factor I concentrations results in increased resorption rates in vivo. Human Reproduction 17 457-462. (doi:10.1093/humrep/ 17.2.457)

Ponsuksili S, Wimmers K, Adjaye J \& Schellander K 2002 A source of expression profiling in single preimplantation bovine embryos. Theriogenology 57 1611-1624. (doi:10.1016/S0093-691X(02)00661-1)

Prelle K, Stojkovic M, Boxhammer K, Motlik J, Ewald D, Arnold GJ \&

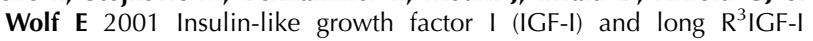
differently affect development and messenger ribonucleic acid abundance for IGF-binding proteins and type I IGF receptors in in vitro produced bovine embryos. Endocrinology 142 1309-1316. (doi:10.1210/en.142.3.1309)

Racedo SE, Wrenzycki C, Herrmann D, Salamone D \& Niemann H 2008 Effects of follicle size and stages of maturation on mRNA expression in bovine in vitro matured oocytes. Molecular Reproduction and Development 75 17-25. (doi:10.1002/mrd.20770)

Rho GJ, Balasubramanian S, Kim DS, Son WJ, Cho SR, Kim JG, Kumar MB \& Choe SY 2007 Influence of in vitro oxygen concentrations on preimplantation embryo development, gene expression and production of Hanwoo calves following embryo transfer. Molecular Reproduction and Development 74 486-496. (doi:10.1002/mrd.20502)

Rubinstein M, Idelman G, Plymate SR, Narla G, Friedman SL \& Werner H 2004 Transcriptional activation of the IGF-I receptor gene by the KLF6 tumor suppressor protein: potential interactions between KLF6 and p53. Endocrinology 145 3769-3777. (doi:10.1210/en.2004-0173)

Schmid P, Lorenz A, Hameister H \& Montenarh M 1991 Expression of p53 during mouse embryogenesis. Development 113 857-865.

Sirisathien S, Hernandez-Fonseca HJ \& Brackett BG 2003 Influences of epidermal growth factor and insulin-like growth factor-I on bovine blastocyst development in vitro. Animal Reproduction Science 77 21-32. (doi:10.1016/S0378-4320(02)00272-5)

Smith RM, Garside WT, Aghayan M, Shi CZ, Shah N, Jarett L \& Heyner S 1993 Mouse preimplantation embryos exhibit receptor-mediated binding and transcytosis of maternal insulin-like growth factor I. Biology of Reproduction 49 1-12. (doi:10.1095/biolreprod49.1.1)

Van Soom A, Boerjan ML, Bols PEJ, Vanroose G, Lein A, Coryn M \& de Kruif A 1997 Timing of compaction and inner cell allocation in bovine embryos produced in vivo after superovulation. Biology of Reproduction 57 1041-1049. (doi:10.1095/biolreprod57.5.1041)

Van Soom A, Yuan YQ, Peelman LJ, de Matos DG, Dewulf J, Laevens H \& de Kruif A 2002 Prevalence of apoptosis and inner cell mass allocation in bovine embryos cultured under different oxygen tensions with or without cysteine addition. Theriogenology 57 1453-1465. (doi:10.1016/S0093691X(01)00726-9)

Spanos S, Becker DL, Winston RML \& Hardy K 2000 Anti-apoptotic action of insulin-like growth factor-I during human preimplantation embryo development. Biology of Reproduction 63 1413-1420. (doi:10.1095/ biolreprod63.5.1413)

van der Spuy ZM \& Dyer SJ 2004 The pathogenesis of infertility and early pregnancy loss in polycystic ovary syndrome. Best Practice \& Research. Clinical Obstetrics \& Gynaecology 18 755-771. (doi:10.1016/j. bpobgyn.2004.06.001)

Stojanov T \& O'Neill C 2001 In vitro fertilization causes epigenetic modifications to the onset of gene expression from the zygotic genome in mice. Biology of Reproduction 64 696-705. (doi:10.1095/biolreprod64. 2.696)

Thierry van Dessel HJH, Lee PDK, Faessen G, Fauser BCJM \& Giudice LC 1999 Elevated serum levels of free insulin-like growth factor I in polycystic ovary syndrome. Journal of Clinical Endocrinology and Metabolism 84 3030-3035. (doi:10.1210/jc.84.9.3030)
Thouas GA, Korfiatis NA, French AJ, Jones GM \& Trounson AO 2001 Simplified technique for differential staining of inner cell mass and trophectoderm cells of mouse and bovine blastocysts. Reproductive Biomedicine Online 3 25-29. (doi:10.1016/S1472-6483(10)61960-8)

Tolivia J, Navarro A, del Valle E, Perez C, Ordoñez C \& Martínez E 2006 Application of Photoshop and Scion Image analysis to quantification of signals in histochemistry, immunocytochemistry and hybridocytochemistry. Analytical and Quantitative Cytology and Histology 28 43-53.

Torchinsky A \& Toder V 2010 Mechanisms of the embryo's response to embryopathic stressors: a focus on p53. Journal of Reproductive Immunology 85 76-80. (doi:10.1016/j.jri.2010.01.003)

Toyoshima M 2009 Analysis of p53 dependant damage response in spermirradiated mouse embryos. Journal of Radiation Research 50 11-17. (doi:10.1269/jrr.08099)

Velazquez MA 2008 Assisted reproductive technologies in cattle: application in livestock production, biomedical research and conservation biology. Annual Review of Biomedical Sciences 10 36-62.

Velazquez MA, Spicer LJ \& Wathes DC 2008 The role of endocrine insulinlike growth factor-I (IGF-I) in female bovine reproduction. Domestic Animal Endocrinology 35 325-342. (doi:10.1016/j.domaniend.2008. 07.002)

Velazquez MA, Zaraza J, Oropeza A, Webb R \& Niemann H 2009 The role of IGF-1 in the in vivo production of bovine embryos from superovulated donors. Reproduction 137 161-180. (doi:10.1530/REP-08-0362)

Wang HS \& Chard T 1999 IGFs and IGF-binding proteins in the regulation of human ovarian and endometrial function. Journal of Endocrinology 161 1-13. (doi:10.1677/joe.0.1610001)

Wang LM, Feng HL, Ma YZh, Cang M, Li HJ, Yan Zh, Zhou P, Wen JX, Bou S \& Liu DJ 2009 Expression of IGF receptors and its ligands in bovine oocytes and preimplantation embryos. Animal Reproduction Science 114 99-108. (doi:10.1016/j.anireprosci.2008.09.019)

Warzych E, Wrenzycki C, Peippo J \& Lechniak D 2007 Maturation medium supplements affect transcript level of apoptosis and cell survival related genes in bovine blastocyst produced in vitro. Molecular Reproduction and Development 74 280-289. (doi:10.1002/mrd.20610)

Watson AJ, Hogan A, Hahnel A, Wiemer KE \& Schultz GA 1992 Expression of growth factor ligand and receptor genes in the preimplantation bovine embryo. Molecular Reproduction and Development 31 87-95. (doi:10. 1002/mrd.1080310202)

Xie D, Chen CC, Ptaszek LM, Xiao S, Cao X, Lewin HA, Cowan C \& Zhong S 2010 Rewirable gene regulatory networks in the preimplantation embryonic development of three mammalian species. Genome Research 20 804-815. (doi:10.1101/gr.100594.109)

Yaseen MA, Wrenzycki C, Herrmann D, Carnwath JW \& Niemann H 2001 Changes in the relative abundance of mRNA transcripts for insulin-like growth factor (IGF-I and IGF-II) ligands and their receptors (IGF-IR/IGFIIR) in preimplantation bovine embryos derived from different in vitro systems. Reproduction 122 601-610. (doi:10.1530/rep.0.1220601)

Yoshida Y, Miyamura M, Hamano S \& Yoshida M 1998 Expression of growth factor ligand and their receptor mRNAs in bovine ova during in vitro maturation and after fertilization in vitro. Journal of Veterinary Medical Science 60 549-554. (doi:10.1292/jvms.60.549)

Yoshida M, Obata R \& Tsujii H 2009 Effect of relaxin and IGF-1 on the preimplantation development of Mongolian gerbil (Meriones unguiculatus) embryos in vitro. Reproductive Medicine and Biology 8 39-43. (doi:10.1007/s12522-008-0007-4)

Zaraza J, Oropeza A, Velazquez MA, Korsawe K, Herrmann D, Carnwath JW \& Niemann H 2010 Developmental competence and mRNA expression of preimplantation in vitro-produced embryos from prepubertal and postpubertal cattle and their relationship with apoptosis after intraovarian administration of IGF-1. Theriogenology 74 75-89. (doi:10.1016/j.theriogenology.2009.11.033)

Received 4 August 2010

First decision 22 September 2010

Accepted 6 October 2010 